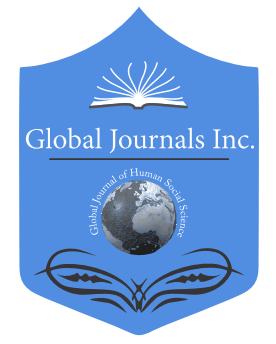

GLOBAL JOURNAL OF HUMAN-SOCIAL SCIENCE: B

GeOGRAPHY, GEO-SCIENCES, ENVIRONMENTAL SCIENCE \& DisASTER MANAGEMENT

Volume 21 Issue 4 Version 1.0 Year 2021

Type: Double Blind Peer Reviewed International Research Journal

Publisher: Global Journals

Online ISSN: 2249-460X \& Print ISSN: 0975-587X

\title{
An Assessment of Fire Hazard in the Historic Town of Ouro Preto based on Four Established Analysis Methodologies
}

By Kruger, Paulo Gustavo Von, Silva, Fernando José, Lasmar, Erika Esteves, Felippe, Anna Rita Tomich Magalhães, Castanheira, Ana Carolina, Oliveira, Crisley Nayanne \& Gonçalves, Luana Oliveira

Federal University of Minas Gerais

Abstract- This work aims to present a comparison of 4 (four) analysis methodologies of the fire risks in historical sites. These analysis methodologies are the following: Ebrafire, Chichorro, Gretener and Multicriteria. The Town area under study is bordered by Tiradentes Square, Senador Rocha Lagoa Street, Conêgo Camilo Veloso by street and Cônego de Bobadela Street in the historic center of Ouro Preto.

The comparative analysis among the four methodologies presented discrepancies in the degrees of fire hazards. However the block assessed presents a high risk of fire, since the great majority of buildings in the area received insufficient fire safety results.

Therefore, although the results here are not conclusive, since this research is in the initial phase, it is already possible to verify the urgency of mitigation actions to reduce the risk of fire in most buildings in the evaluated block.

Keywords: risk assessment methodology - fire risk management - historical sites -vulnerability - resilience - mitigation actions.

GJHSS-B Classification: FOR Code: 040699p

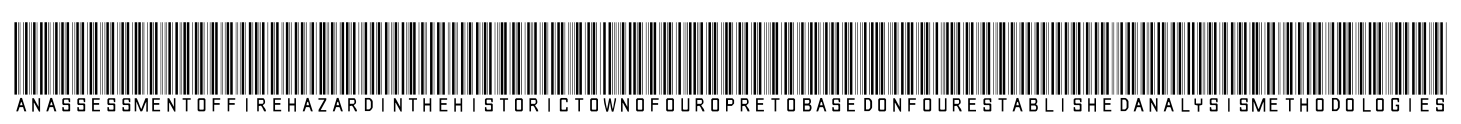

Strictly as per the compliance and regulations of:

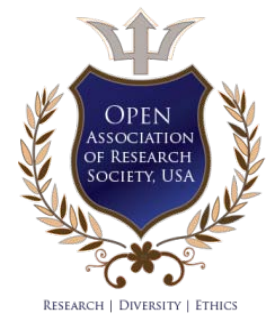

(C) 2021. Kruger, Paulo Gustavo Von, Silva, Fernando José, Lasmar, Erika Esteves, Felippe, Anna Rita Tomich Magalhães, Castanheira, Ana Carolina, Oliveira, Crisley Nayanne \& Gonçalves, Luana Oliveira. This research/review article is distributed under the terms of the AttributionNonCommercial-NoDerivatives 4.0 International (CC BY-NC-ND 4.0). You must give appropriate credit to authors and reference this article if parts of the article are reproduced in any manner. Applicable licensing terms are at https://creativecommons.org/licenses/by-nc-nd/4.0/. 


\title{
An Assessment of Fire Hazard in the Historic Town of Ouro Preto based on Four Established Analysis Methodologies
}

\author{
Kruger, Paulo Gustavo Von ${ }^{\alpha}$, Silva, Fernando José ${ }^{\circ}$, Lasmar, Erika Esteves ${ }^{\circ}$, \\ Felippe, Anna Rita Tomich Magalhães ${ }^{\omega}$, Castanheira, Ana Carolina ${ }^{\ddagger}$, Oliveira, Crisley Nayanne ${ }^{\S}$ \\ \& Gonçalves, Luana Oliveira ${ }^{x}$
}

Abstract- This work aims to present a comparison of 4 (four) analysis methodologies of the fire risks in historical sites. These analysis methodologies are the following: Ebrafire, Chichorro, Gretener and Multi-criteria. The Town area under study is bordered by Tiradentes Square, Senador Rocha Lagoa Street, Conêgo Camilo Veloso by street and Cônego de Bobadela Street in the historic center of Ouro Preto.

The comparative analysis among the four methodologies presented discrepancies in the degrees of fire hazards. However the block assessed presents a high risk of fire, since the great majority of buildings in the area received insufficient fire safety results.

Therefore, although the results here are not conclusive, since this research is in the initial phase, it is already possible to verify the urgency of mitigation actions to reduce the risk of fire in most buildings in the evaluated block. Therefore, mitigation actions coroborates for a policy of immediate fire risk management.

Keywords: risk assessment methodology - fire risk management - historical sites - vulnerability - resilience mitigation actions.

\section{InTRODUCTION}

A ccording to the normative instruction number 01 dated August 24, 2012 of the Ministry of National Integration (Brazil), "disaster is a result of an adverse event, natural or man-made, under a vulnerable ecosystem, using human material of environmental damage in addition to economic and social damage" (Brazil 2012), and they can be classified, as to primary cause in:

- Natural: Arising from natural process or natural phenomena that may result in human losses or other impacts on health, damage to the environment, property, interruption of services and economic disturbances.

- Technological: Arising from accidents, dangerous procedures, infrastructure failures or specific human actions.

Author $\alpha \sigma \rho ¥ \S \chi$ : Federal University of Minas Gerais Brazil. e-mails: paulovonkruger@gmail.com, fernandojsilva@ufmg.br, ana023carolina@gmail.com,crisleynaol@gmail.com, luaholiveira96@gmail.com, erika_lasmar@yahoo.com.br Author w: Federal University of Itajubá Campus Itabira, Brazil. e-mail: annarita@unifei.edu.br
According to the above paragraph, fires in buildings and historic sites are part of technological disasters, and their management can be a way of protecting cultural assets. In this sense, it is important to understand the concepts of vulnerability and resilience:

- Vulnerability: is the fragility of the place to withstand impacts, which is susceptible to the adverse effects of a hazard:

- Resilience: is the "capacity of a system and its components to anticipate, absorb, adapt to or recover from the effects of a hazardous event in a quick and efficient manner, including ensuring prevention, restoration or improvement of basic essential structures and functions" (IPCC, 2012).

Fire risk management helps to increase the resilience of a given social group, where possible vulnerabilities can be detected before a disaster occurs, and mitigation measures can be adopted.

Risk and Disaster Management (DRM) works with five phases: preparation, mitigation, prevention, response and recovery. The Sendai Framework (ALVES, 2016) recommends risk management based on four action priorities:

Priority 1: Understanding disaster risk;

Priority 2: Strengthening governance to manage disaster risk;

Priority 3: Investing in disaster risk reduction for resilience;

Priority 4: Improve preparedness to respond effectively and rebuild better recovery, rehabilitation and reconstrucion.

At the time of a disaster, communication networks and the technologies associated with them are crucial elements to plan emergencies and provide essential assistance to victims (COYLE AND MEIER, 2009). New technologies and their uses allow to improve prevention, planning and response capacities in times of crisis (ROCHE, PROPECK-ZIMMERMANN and MERICSKAY, 2013)

As confirmed by KLEIN, LUTZ and KUHN (2006), the processes related to crisis management are 
based on geographical information and technology associated. The development of new technologies and information and communication, such as cell phones, internet, social networks or online mapping, has opened the way for new information manipulation practices. (ROCHE, PROPECK-ZIMMERMANN and MERICSKAY, 2013).

Geographical data and its tools are essential in all aspects of emergency management: preparation, response, recovery and mitigation. During emergencies, time is essencial (GOODCHILD and GLENNON, 2010).

According to Serpa (2009), some aspects can increase the risks of a fire, make difficult or prevent its combat and extinction, or cause the structural collapse of the building. Ouro Preto, the city chosen for the application of these methodologies, has favorable characteristics both from a heritage point of view - one of the first cities listed by IPHAN (1930) and the first Brazilian city declared by UNESCO as a World Heritage Site (1980) - and for the probability of fire propagation. These aspects are the following:

- Constructive characteristics of the building constructive elements such as floors, ceilings, stairs made of wood;

- Construction of buildings in urban centers without gaps between buildings and expansions or irregular occupations in the core of the blocks enabling the rapid spread of flames;

- Lack of proper maintenance of buildings and their facilities;

- Change in the type of occupation without the proper adaptations for its new use;

- Adaptations for electrical installations and liquefied gas - LPG to adapt the building to the new use.

Due to the isolated location of the territory and difficult access, the materials available in the region and the workforce with their own techniques predominated, associated with the influences of the Baroque in force in the metropolis in the 17th century (VASCONELOS, 1951). It can be said, therefore, that vernacular architecture, the one built with local techniques and materials, has become characteristic, even for the simplicity of its form (BAETA, 2002).

The unstable situation experienced by the explorers, as their permanence in the place varied according to the results of gold extraction, meant that the buildings were erected in a temporary and simplified manner. Wattle and daub, wood or stone walls - the latter more like a foundation - and straw, palm trees or thatch roofs were the most used in colonial buildings in Minas Gerais. Wood was, still is, widely used from those hardwood to props and purlins for constructions of relative weight.

At a time when a Master Plan was a distant reality, and little was said about urban planning in the then Portuguese Colony, the territory was occupied according to the potential of the discovered gold mines, generally obeying the dominant direction parallel to the contour lines.

The dwellings were built side by side, without separation, in basic types of construction, with streams in the background. The central strategic position of religious buildings contributed as a reference point to encourage urbanization for the layout of the camp, carrying out the settlement of its inhabitants around open spaces, in the case of chapels (VASCONCELLOS, 1951).

The steep and curvy streets, with a short visual field, - which delay and/or prevent the passage of Fire Department vehicles, in addition to the extreme proximity of the buildings and the materials used in them, makes Ouro Preto an authentic "flammable city", as explained by CLARET de GOUVEIA (2017).

\section{il. Methods and Processes}

For the execution of this research, the georeferenced data was obtained, from-previous research developed by the Geoprocessing Laboratory of the School of Architecture of the Federal University of Minas Gerais (UFMG) These data were used to simulate scenarios for predictive studies related to fire risk assessment through four methodologies: Chichorro Method (CHICHORRO, FERREIRA and CORREIA, 2016), EBRAFire Method (SILVA et al, 2020), Gretener Method, and the Multicriteria Method (LASMAR, 2020).

It is important to point out that the first two methodologies mentioned are being used through a partnership between the Universities of Porto and Beira Interior (both from Portugal), respectively, and the School of Architecture of the Federal University of Minas Gerais (EA-UFMG), Brazil.

\section{a) Chichorro Method}

The Chichorro Method (Holistic Calculation of the Construction Fire Risk and Enabled Optimization of its Reduction with Works) is a Fire Risk assessment model developed at the University of Porto (UP), Portugal, and which was born out of the concern from the analysis of buildings built in historic sites due to the increasing occurrence of urban fires, some of them of high severity, and the quantification of the impact that a fire started in a building may have.

This method is based on four global fire risk factors:

- Probability of fire occurrence;

- Total consequences of the fire;

- Development and spread of fire; and

- Effectiveness of fire relief and firefighting.

Through these four global factors, the methodology covers all aspects that relate to the calculation of fire risk, resulting in the translation of risks for users of a given building, in addition to the goods 
contained therein (CHICHORRO, FERREIRA and CORREIA, 2016).

b) EBRAFire

EBRAFire, developed at the University of Beira Interior (UBI), Portugal, assigns a classification to the buildings analyzed, based on fundamental parameters, observed in empirical events, technical and regulatory standards. It has an intuitive layout in order to facilitate the entry of data, a field form in checklist format and a form with a summary of the results obtained in the procedure. EBRAFire also allows for a detailed analysis of the parameters to understand its contribution to the building's fire safety (SILVA et al, 2020).

The final result of the fire safety classification is the analytical comparison organized into four subchapters:

- Subchapter A, analyzes fire safety from the building's physical characteristics, location, materials and content;

- Subchapter B, studies the factors that contribute to the safety of users, such as behavior, activities and availability of means of combat;

- Subchapter $\mathrm{C}$, examines the function of the space around the building and its contribution to fire and ignition safety, such as vegetation and adjacent buildings, as well as entrances;

- Subchapter D, observes safety measures applied to activities that occur adjacent to or within structures (fairs and cultural festivals, for example) (MOREIRA, 2018).

\section{c) Gretener's Method}

Created by engineer Max Gretener in 1960 at the time he was director of the Fire Protection Association in Switzerland, it was initially used to serve insurance companies. In 1968, it was adopted as a means of fire risk assessment by the Swiss Fire Department.

The method consists of determining a safety factor for each compartment of the building. It is a mathematical relationship where the numerator represents fire safety factors and the denominator represents fire risk factors. Fire safety will be verified if all safety factors are greater than or equal to one (SILVA and COELHO FILHO, 2007).

In this work, the version of the methodology contained in Technical Instruction 35 of the Minas Gerais Military Fire Department (CBMMG) was adopted, an adaptation proposed by Professor Antônio Maria Claret de Gouveia of the Federal University of Ouro Preto (UFOP), (CBMMG, 2018).

In this adaptation, fire safety is measured by assigning weights to nineteen factors represented by fire signaling measures, fire extinguishing (permanent fire brigade, for example), infrastructure (existence of fire hydrants inside the building), measures to protect building structures and safety measures, such as signage for emergency exits and escape routes (CBMMG, 2018).

Fire risk is defined by the product of a determined quantity that expresses the exposure to fire risk (or fire hazard) by a probable quantity that expresses the risk of fire activation (CBMMG, 2018).

\section{d) Multicriteria Method}

Finally, the Multicriteria Method (MCA), which is "a set of tools and mathematical methods that allow the comparison of different alternatives according to many criteria, often contradictory, in order to guide the decision maker to a judicious choice" (CHAKHAR and MOUSSEAU, 2008).

To carry out the MCA, it was necessary to define the objectives to be achieved, the variables of this process and their weights of importance. The distance between buildings, the ease of access for Fire Department vehicles, the concentration of fire load, the distance from the nearest fire hydrant, the existence (or not) of the Fire Department Inspection Report (AVCB), the state conservation of the building and the adequacy of electrical standards are some of the criteria adopted in this methodology (LASMAR, 2020).

\section{ili. Space Cutting}

The city chosen for the risk assessment was Ouro Preto. Located in the central region of Minas Gerais, the city of Ouro Preto has the largest and most important collection of architecture and art from the colonial period in all of Brazil. Due to its size and conservation, Ouro Preto was one of the first cities chosen by the United Nations Educational, Scientific and Cultural Organization (Unesco) to be a World Heritage Site in 1980 (MINAS GERAIS, 2019).

According to Claret de Gouveia (2017), Ouro Preto can be considered a flammable city due to its characteristics of urban implantation (buildings without lateral spacing and narrow streets), geographic (great hills and valleys) and construction characteristics (use of wood in floors, stairs, balconies etc). According to the author, the term flammable city "intended to designate formerly existing cities, which, given their great vulnerability and reduced security, had large areas destroyed under the action of widespread fires." (CLARET de GOUVEIA, 2017, p.15).

For the first phase of this research (still in progress), the block bordered by Tiradentes Square, Senador Rocha Lagoa street, Cônego Camilo Veloso by street and Conde de Bobadela street (Figure 2) was chosen. 


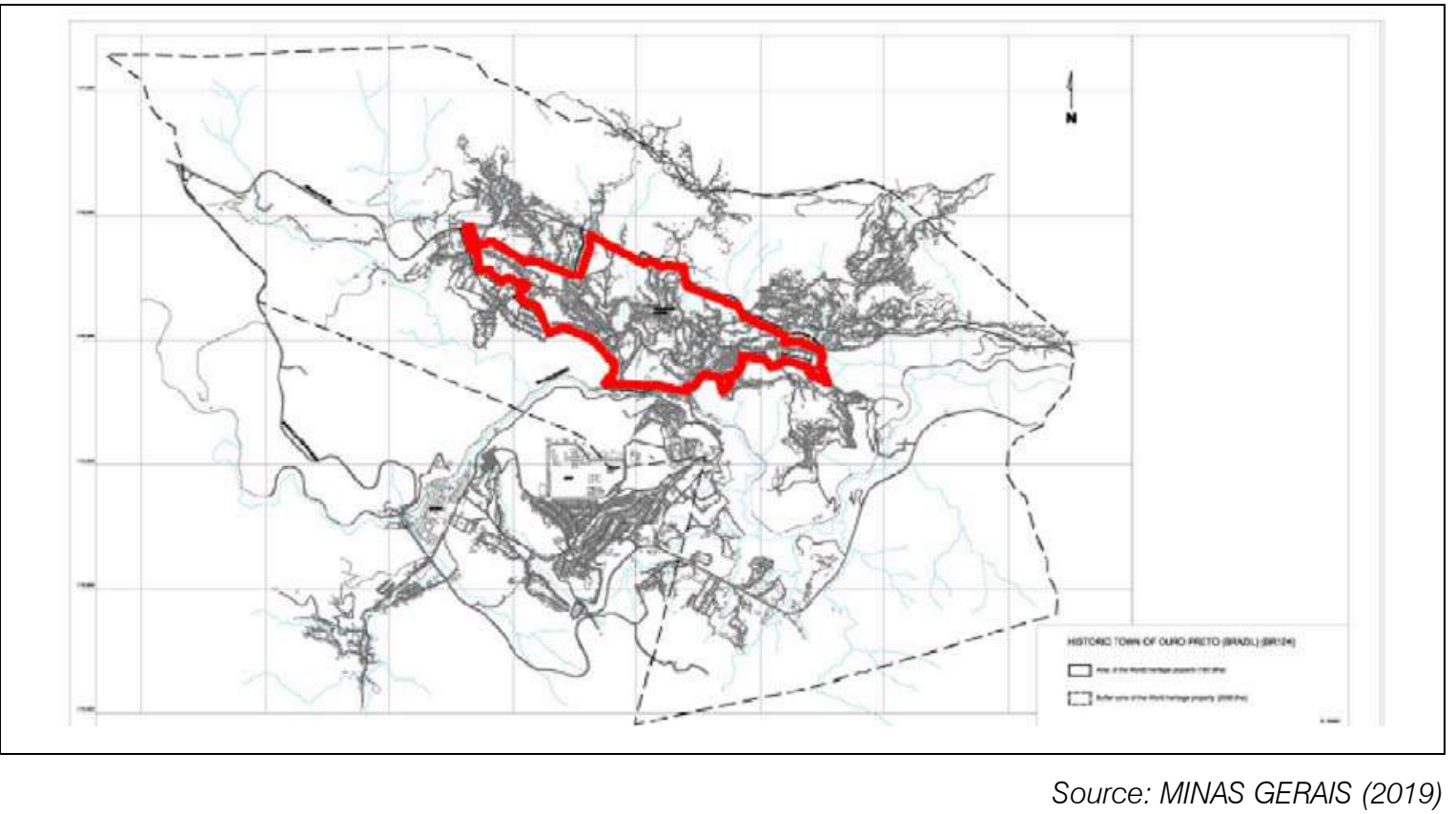

Figure 1: Ouro Preto Historical Center (highlighted in red).

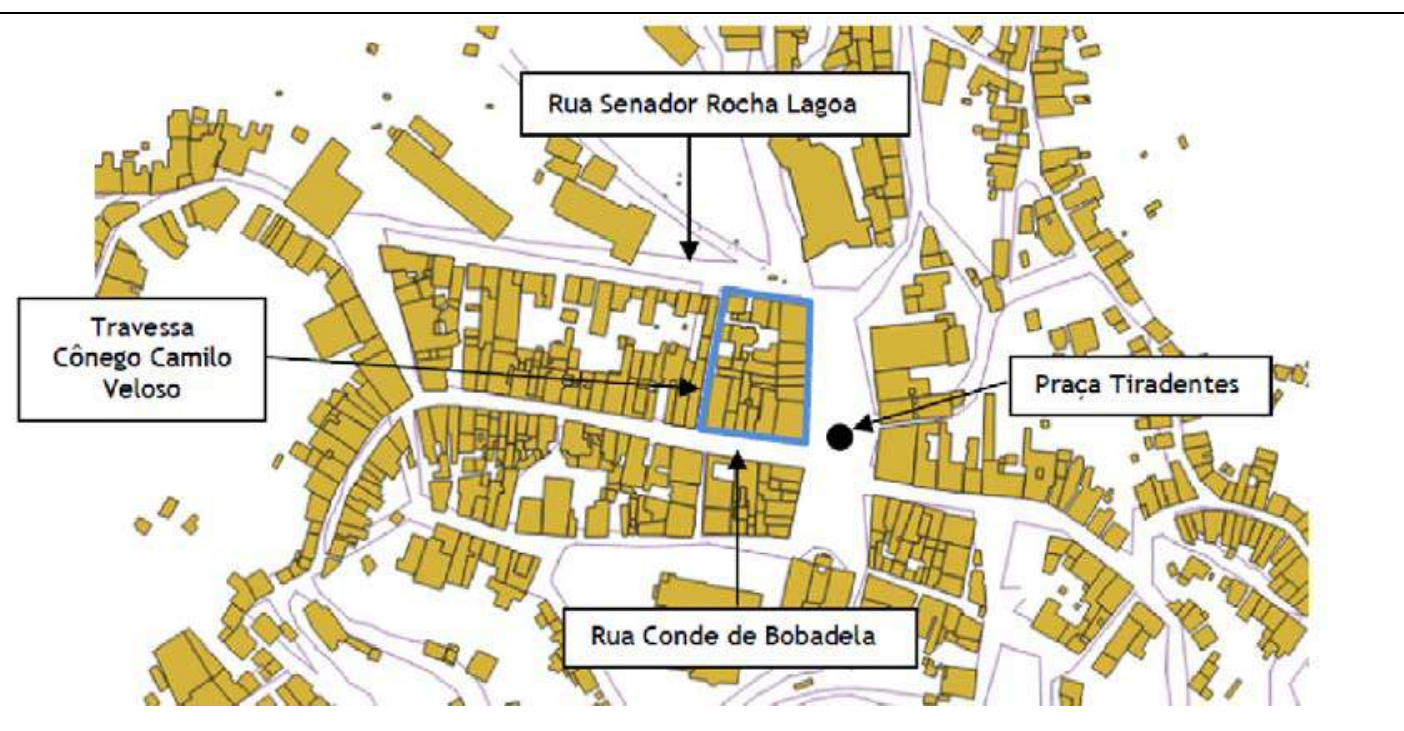

Source: Image prepared by the Geoprocessing Laboratory of the School of Architecture of the Federal University of Minas Gerais.

Figure 2: Area chosen for the study (highlighted in blue), within the Historic Center of Ouro Preto. 


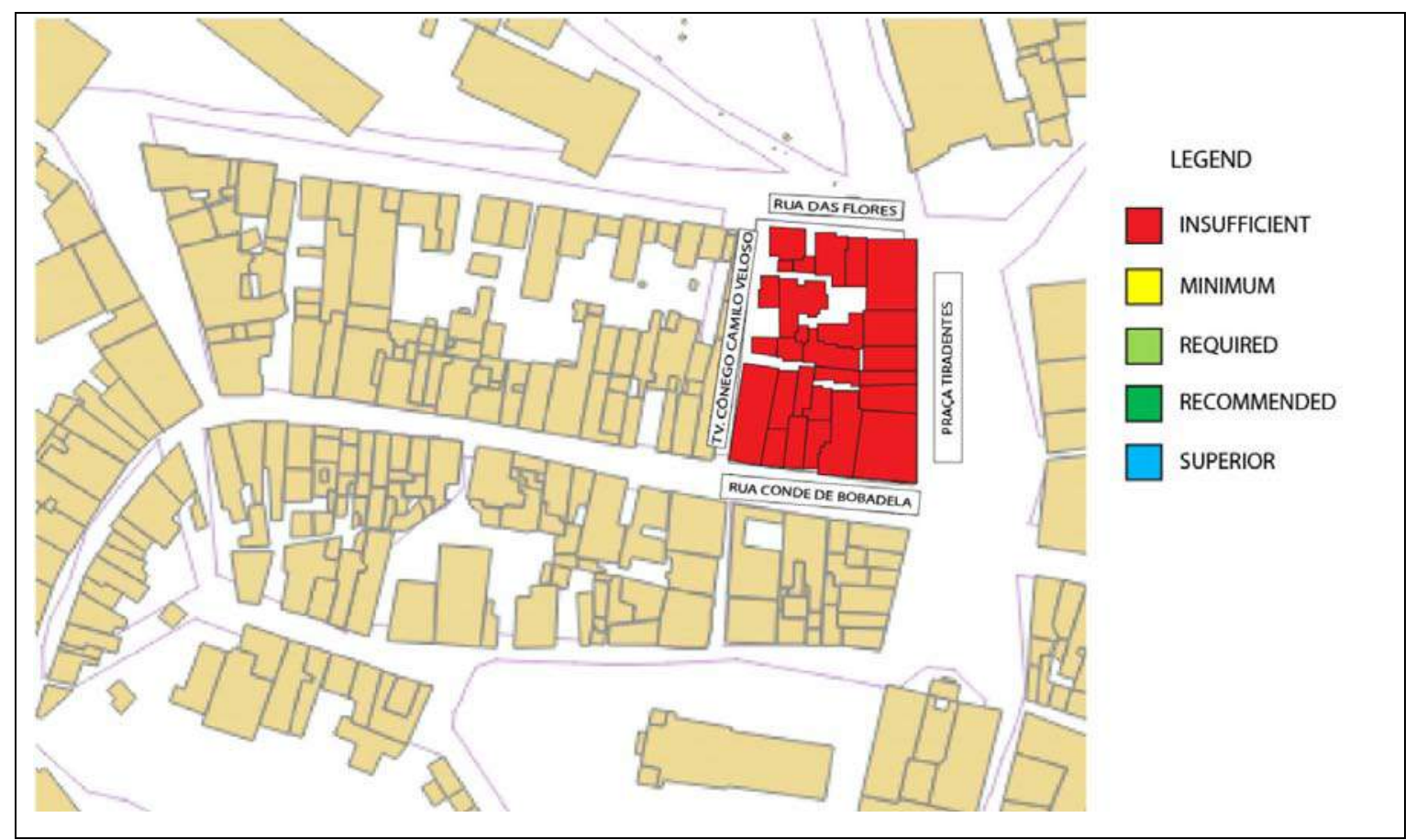

Source: Image prepared by the Fire Science and Technology Research Group - IGNIS

Figure 3: Fire risk assessment using EBRAFire.

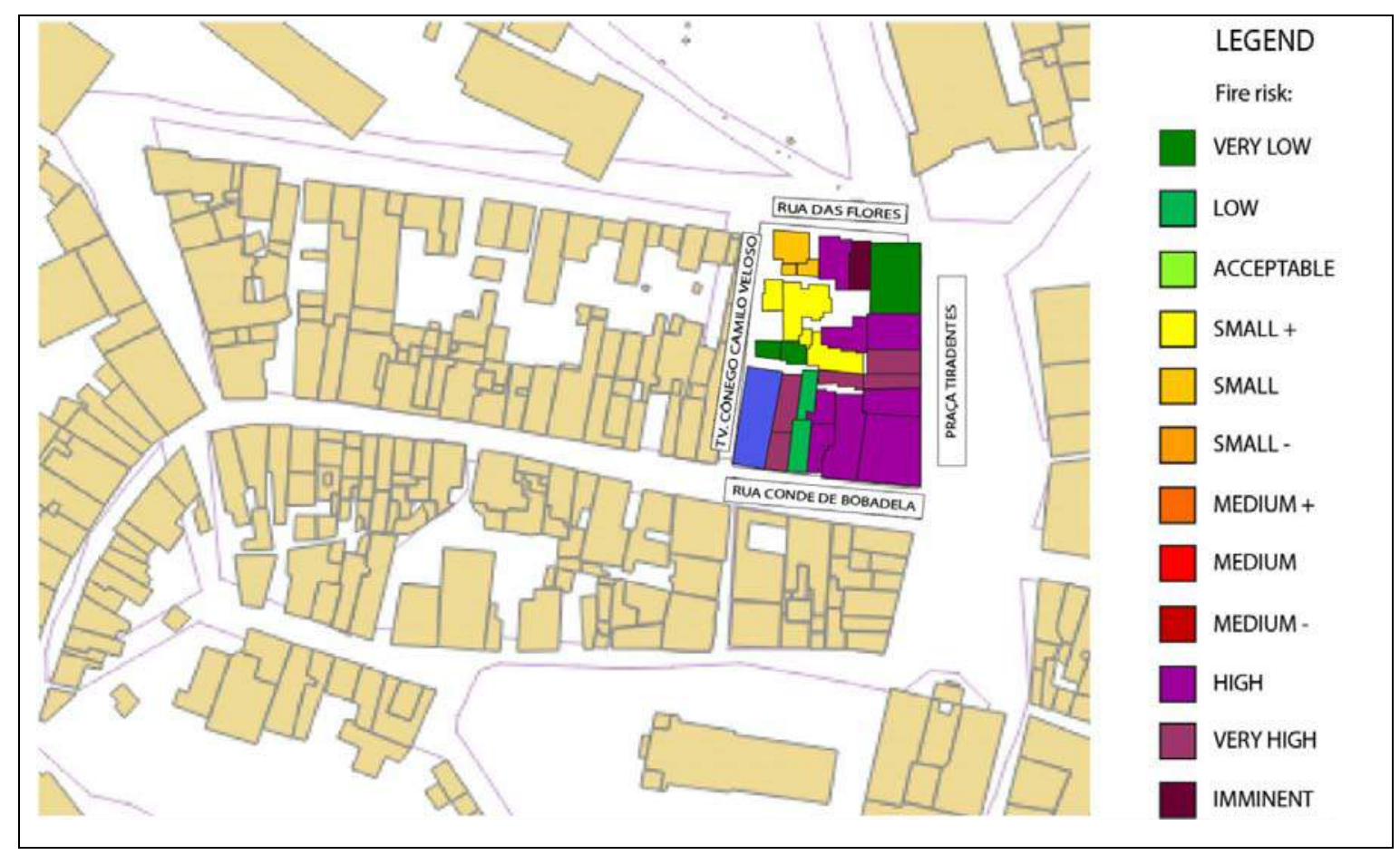

Source: Image prepared by the Fire Science and Technology Research Group - IGNIS Figure 4: Fire risk assessment using Chichorro. 


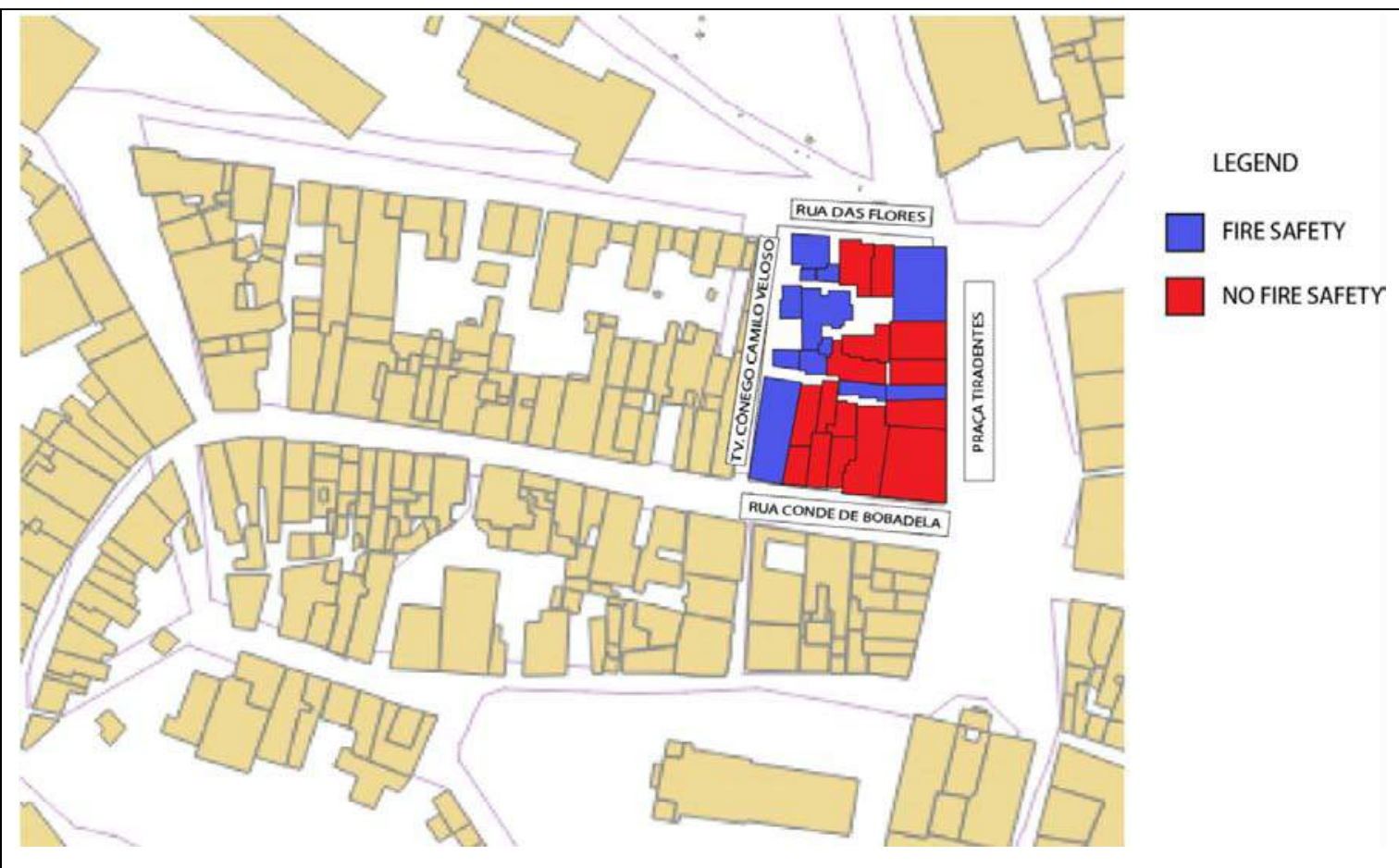

Source: Image prepared by the Fire Science and Technology Research Group - IGNIS

Figure 5: Fire risk assessment using Gretener.

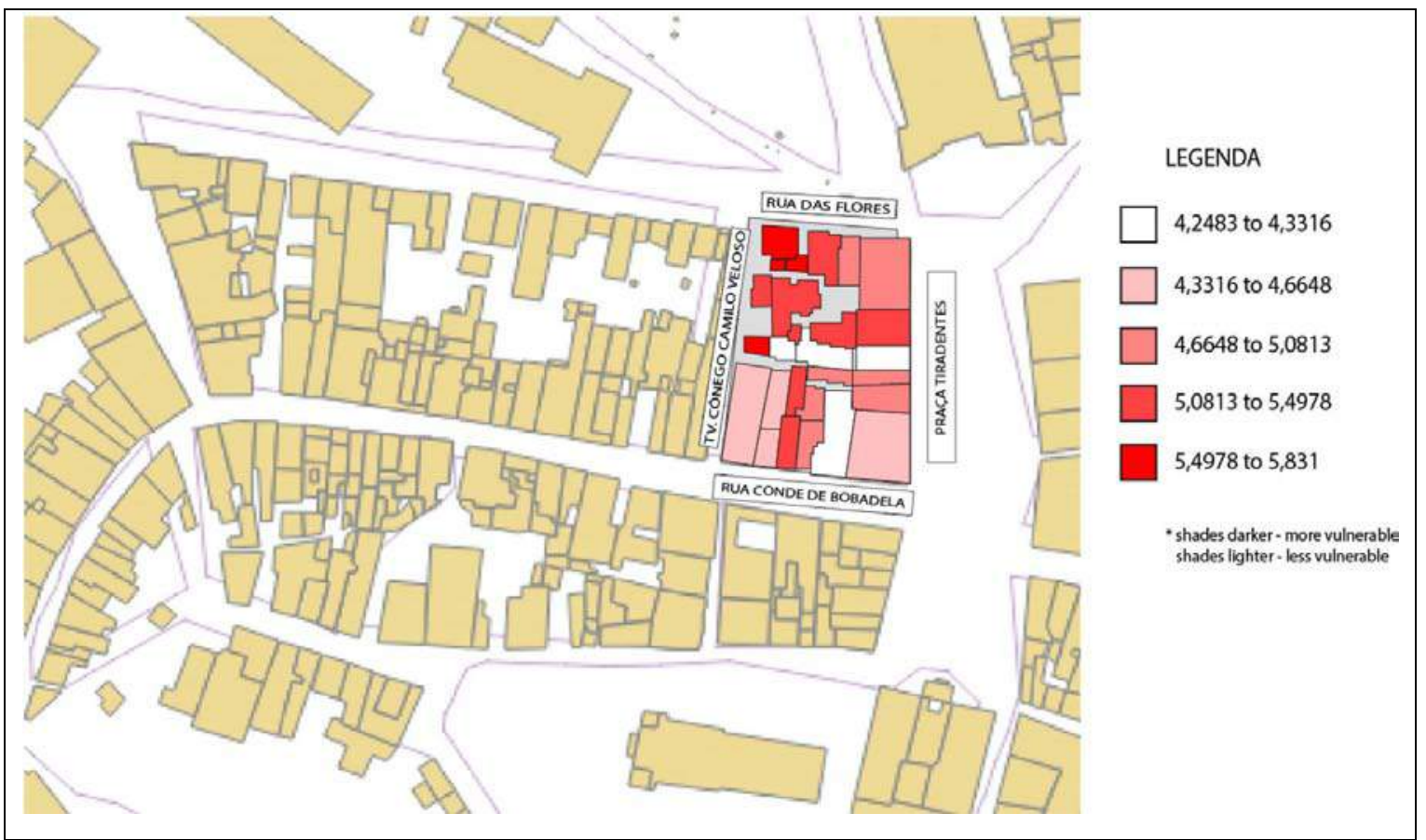

Source: Image prepared by the Fire Science and Technology Research Group - IGNIS

Figure 6: Fire risk assessment using MCA.

Figure 6 shows the MCA result in color grading, according to the degree of vulnerability, ranging from darker tones, greater vulnerability, to lighter tones, with less vulnerability.
In Figure 3, all fourteen buildings analyzed had an insufficient fire safety level, according to EBRAFire. In Figure 4, two of these buildings were classified as $\mathrm{A}++$ and one, $A+$, through the Chichorro Method. However, 
the other buildings have similar degrees of fire risk, with C- (medium fire risk) D (high fire risk), E (very high fire risk) and $F$ (imminent fire risk), the classes of risk obtained by Chichorro.

Figure 5 presents the results of the evaluation using the Gretener Method. Only thirteen of the seventeen buildings were evaluated, as some data were not obtained due to the social isolation imposed by the Covid 19 virus pandemic. Even so, it is clear that only two buildings, of all analyzed, "have fire safety".

Finally, when analyzing the results obtained with the MCA (Figure 6), it appears that there is a greater number of buildings with a greater degree of vulnerability.

As they are different evaluation methodologies, it was expected that different results could occur, a fact confirmed through the analysis presented here. EBRAFire analyzes the degree of safety based on the characteristics of the building and its surroundings and the safety of its users, Chichorro evaluates the building's performance, the probability of occurrence, the development and severity of a fire, Gretener, the ratio between fire safety factors and fire risk factors, and the MCA, sometimes conflicting pre-established criteria.

However, regardless of the methodology, it is notable to observe that most buildings (if not all, as in the case of EBRAFire) have a high degree of fire risk. Added to this are characteristics such as the implementation of buildings (no removal), changes in use and occupation and adaptations without monitoring or knowledge of the competent authorities (City Hall, IPHAN and Fire Department), greatly increasing the probability of a fire on a large scale.

It was found, for example, that some buildings that have a high degree of risk in two of the four methodologies (EBRAFire and Chichorro), have a Fire Prevention and Fire Fighting Policy. However, other items evaluated, such as state of conservation and nonexistence of escape routes, increased the degree of risk of some buildings; others do not even have a Fire Prevention and Fighting Policy. This means that such buildings lack fire-fighting equipment, alarm systems, heat and smoke detection, among other items.

It is noteworthy that the research is in its initial phase and evaluations of other areas within the historic center of Ouro Preto will tend to be similar, since the entities involved (residents, tenants and users) and the physical attributes (implementation, materials and construction techniques) have similar characteristics.

There is still the incompleteness of collected data. The collection of data is still incomplete as of this writing. This is due to the fact that several buildings still have not adopted the Fire Prevention and Fighting Policy, making it difficult to collect data from the Minas Gerais Military Fire Department for the city of Ouro Preto. Added to this was the beginning of social isolation imposed by the Covid 19 virus pandemic, which made it impossible to continue the research from March 2020 onward.

\section{Final Considerations}

This work presented the first data of a still incipient research, started in the first half of 2019. This means that conclusive information will be reached over the next few years of its development, including the deepening of the evaluation by obtaining more data related to buildings and the expansion of this assessment to the entire Historic Center of Ouro Preto.

However, some issues can already be observed with the data obtained so far: the evaluated block presents a high risk of fire, since most of the buildings that are located there obtained insufficient results for fire safety.

This degree of risk can be increased if we consider the characteristics mentioned above, such as: constructive materials for the buildings there (wooden floors, ceilings and stairs); the implantation of buildings without gaps between buildings; expansions or irregular occupations in the core of the courts (providing the rapid spread of the flames), the lack of adequate maintenance of the buildings and their installations; and the type of occupation changed without adequate adaptations for its adaptation (electrical installations, for example) (SERPA, 2009).

Therefore, it is noteworthy that, although the results presented here are not yet conclusive, it is already possible to verify the urgency of the need for mitigating actions to reduce the risk of fire in most buildings in the assessed block, which corroborates a need for an imminent fire risk management policy.

In time, this approach will provide subsidies to increase resilience in this type of location, since the most vulnerable areas will be identified and mitigating actions can be established before a fire occurs.

\section{References Références Referencias}

1. ALVES, H. R. A Gestão de Riscos de Desastres Naturais no Brasil: face as mudanças sociais e ambientais desencadeadas pelo processo de urbanização. 1. Ed. - Curitiba: Editora Prisma, 2016.

2. BAETA, Rodrigo. OURO PRETO cidade barroca. Cadernos PPG-AU/UFBA. v.1, n. 1, 2002.

3. BRASIL. Ministério da Integração Nacional. Instrução Normativa No 01, de 24 de Agosto de 2012. It establishes procedures and criteria for the decree of emergency situation or state of public calamity by the Municipalities, States and the Federal District, and for the federal recognition of abnormal situations decreed by federative entities, and other measures. Available in: https://www. cnm.org.br/cms/images/stories/Links/09062014_Ins trucao_normativa_de_01_de_agosto_de_2012. 
4. CBMMG (Corpo de Bombeiros Militar de Minas Gerais). Instrução Técnica $n^{\circ}$ 35: Segurança contra incêndio em edificações que compõem o Patrimônio Cultural. 2.ed. 2018.

5. CHAKHAR, Salem; MOUSSEAU, V. GIS based multicriteria spatial modeling generic ramework. Paris. International Journal of Geographical Information Science, p. 1159-1196, 2008. DOI: 10. 1080/13658810801949827. Available in: <https:// www.lamsade.dauphine.fr/mcda/biblio/PDF/Chakha rMousseaulJGIS2008.pdf > .

6. CHICHORRO, M., FERREIRA, R., CORREIA, A. Risk Assessment of urban fire - Proposal os a Model for Analysis and Management of Existing Building. INTERNATIONAL CONFERENCE On URBAN RISKS. Lisboa. 2016.

7. CLARET de GOUVEIA, Antônio Maria. Introdução à Engenharia de Incêndio: para estudantes, arquitetos, engenheiros, administradores e bombeiros. Belo Horizonte. 3.ed. 2017.

8. COYLE, D., MEIER, P. New technologies in emergencies and conflicts: the role of information and social networks. Washington, DC: United Nation Fundation \& Fodafone Fundation, 2009.

9. GOODCHILD, M. F., GLENNON, A. Crowdsourcing geographic information for disaster response: a research frontier, International Journal of Digital Earth, 3:3, 231-241, 2010. DOI: 10.1080/1753894 1003759255

10. INTERGOVERNMENTAL PANEL on CLIMATE CHANGE (IPCC). Resumen para responsables de políticas - Informe especial sobre la gestión de los riegos de fenómenos meteorológicos extremos y desastres para mejorar la adaptación al cambio climático. Available in: <https://www.ipcc.ch/>. 2012.

11. KLEIN, E., LUTZ, M., KUHN, W. Ontology-based discovery of geographic information services: An application in disaster management. Computers, Environment and Urban Systems. Volume 30, Issue 1, jan. 2006, pp.102-123.

12. LASMAR. E. E. Uso do SIG, do BIM e de métodos de análise e gestão de riscos de incêndio em patrimônio cultural. Dissertação de mestrado. Universidade Federal de Minas Gerais, 2020.

13. MINAS GERAIS. Governo do Esado de Minas Gerais, Brasil. A cidade de Ouro Preto. Available in: $<$ https://www.mg.gov.br/conteudo/conheca-minas/ turismo/cidade-de-ouro-preto> set. 2019.

14. MOREIRA, L. C. F. Exigências e melhorias nas condições de segurança contra incêndios em edifícios. Trabalho de minidissertação no âmbito da disciplina de Avaliação, Qualidade e Reabilitação de Edifícios, Universidade da Beira Interior, Portugal, jan. [2018].

15. ROCHE, S. PROPECK-ZIMMERMANN, E., MERICSKAY, B. GeoWeb and crisis management: issues and perspectives of volunteered geographic information. Geo Journal. February 2013, Volume 78, Issue 1, pp 21-40. Available in: <https://doi.org/ 10.1007/s10708-011-9423-9>.

16. SERPA, F. B. A segurança contra incêndio como abordagem de conservação do patrimônio histórico edificado: a aplicação do sistema de projeto baseado em desempenho em edifícios históricos em Florianópolis, SC. Dissertação de mestrado. Universidade Federal de Santa Catarina, 2009. $187 \mathrm{p}$.

17. SILVA, Fernando José da; MOREIRA, Luís Carlos Ferreira; LANZINHA, João Carlos Gonçalves; KRÜGER, Paulo Gustavo von. EBRAFire: Fire Safety Assessment and Classification of Buildings. International Journal of Engineering Research and Applications (IJERA) Vol 10, Issue 12, Séries II, Dezembro 2020. Available in: http://ijera.com/ papers/vol10no12/Series-2/J1012025765.pdf.

18. SILVA, Valdir Pignata; COELHO FILHO, Hamilton de Silva. Índice de Segurança contra Incêndio para Edificações. Ambiente Construído. Porto Alegre, v.7, n.4, p. 103-121, out./dez. 2007.

19. VASCONCELLOS, Sylvio de. Arquitetura particular em Vila Rica. Belo Horizonte: [s.n.], Concurso para provimento da cadeira de Arquitetura no Brasil da Escola de Arquitetura da Universidade de Minas Gerais. Obra xerocopiada. 1951. 